\title{
PSYCHO-IMMUNOLOGICAL PROCESS EVALUATION OF BIODANZA
}

\section{SUMMARY}

Introduction. Biodanza is an intervention intended to promote health by encouraging selfexpression and autoregulation through music, dance and interaction as developed by $R$. Toro. Aim of the Study. To examine the effects of Biodanza on the secretion of IgA and the feeling of relaxation before and after the Biodanza sessions in a group of schoolteachers.

Materials and Methods. This study can be supported by other studies with adults, which have established moderate correlations between auto-regulative trainings and increases in the secretion of IgA (Green, R. G., Green, M. L., 1987; Jasnoski, Kugler, 1987; Green, R. G., Green, M. L., Santoro, 1988). Our studies are the first to examine these effects with Biodanza based on 10 points of measurement of IgA. An experimental group (EG, Biodanza) and a control group (CG, STRAIMY ${ }^{\circledR}$,Yoga programme) took part in 10 sessions. Before and after each session IgA and feeling of relaxation were measured. After 10 sessions the EG (Biodanza) continued Biodanza for 10 more sessions.

Results. The subjects out of the EG and the CG showed a significant increase (p $\leq .05)$ in IgA in 6 out of 10 sessions. The effect sizes (concerning IgA) in the first 6 sessions ( $d^{\prime} \geq 1.05$ ) of Biodanza point towards a large difference between pre and post measures. The lack of pre-post-effects from the seventh Biodanza-session onward, in comparision to the CG, may be due to an increase in pre IgA-values in the EG for the first and last sessions on a $10 \%$ significance level with a high effect size (d'=.72). Follow-up examinations after 10 weeks without Biodanza showed that the IgA-group-average-value of the group that did not practice Biodanza between the $10^{\text {th }}$ and the $20^{\text {th }}$ session sank significantly $(p<.05 * *)$.

Conclusions. The results of the IgA measure before and after each session (short term effect) showed a significant increase after the session in both groups (Biodanza, Yoga-Intervention). Therefore, the intended autoregulative effects of Biodanza- and Yoga are responsible. Furthermore, as the results show, that Biodanza could have in this current study a stronger influence for long-term changes concerning the IgA-Immune-Reaction compared to the Yoga-Intervention (STRAIMY ${ }^{\circledR}$ ). This "Transtase"-effect underlines the effect of self-organizing systems, wherein a new quality state (JUMP) in the regulation of IgA is reached. Follow-up examinations proved that Biodanza has to be practiced constantly in order to obtain the immunological changes.

Key words: biodanza, immunoglobulin a, stress management

\section{INTRODUCTION}

What is Biodanza? According to R. Toro (Toro, 1995) Biodanza is intended to encourage psycho-physiologic self-organisation (self-regulation). The experiences in the context of this intervention aim to mobilise "powers of self-healing" and thereby increase feelings of selfconfidence and joy. That way Biodanza does not concentrate so much on the problems but on a person's available resources. It works towards facilitating access to individual abilities and 
strengths already present. R. Toro (Toro, 1995) developed a theoretical model for Biodanza. The basic concepts of this theoretical model (TM) will be explained in the following section.

\section{Integration:}

An important goal of Biodanza in addition to achieving a balanced or well-regulated internal state is the establishment of a state of human integration in the context of the struggle to express one's individual, genetically-determined potential (vertical aspect of TM). L. Biswanger (Biswanger, 1973) was the first to mention the concept of human integration. In Biodanza, integration manifests itself in three aspects:

1. The affective-psychomotor integration of the individual focuses on establishing individual synchrony between thoughts, feelings, and actions.

2. Social integration refers to the integration of the relationships between members of the same species.

3. The third aspect involves the integration of the original relationship between man and nature and the awareness of man's involvement in the greater totality of the cosmos.

The integration takes place through the stimulation of the primal life functions, which we are constantly separated from by the forces of culture (Toro, 1995). A characteristic of the fundamental vision in Biodanza: The integration of the three aspects takes place simultaneously, interactively, not consecutively (Garcia, 1997).

\section{Identity and Regression:}

The horizontal access of the theoretical model represents the continuum between the poles of identity and regression (Garcia, 1997). This continuum refers to the natural alternation between the various states of consciousness and leads to the integration process.

The extreme end of the identity pole is our essence - the intimate feeling of being truly oneself. In this state of consciousness, the world is seen from the very personal standpoint of the individual and a differentiation between subject and other subjects or, in other words, a subjectobject differentiation, is possible. Identity is the consciousness and the experience of being. Identity is not static but changes constantly without losing the essence of its being. In other words: Identity is a heightened awareness of ourselves, wherein we feel ourselves intensely and are active (waking state). A physical dimension of identity is movement, where the physical level of identity expresses itself among other things by means of dance.

Regression is a state of undifferentiated perception and relaxation involving the dissolution of identity. Regression is the reduction or revocation of wilful, cortical activity. This state has a healing, regenerative effect on the organism by stimulating homeostasis. In Biodanza, the regressive state is an experience of harmony of the primal life functions, such as the instincts. In the state of regression we are in touch with our healthy essence, which is distinctly separate from cultural and repressive values. In this state we strengthen the balance and stability of the living system.

Expanding further on the theory represented in the horizontal aspect of his model (identity vs. regression) Toro concluded that every disorder in the biopsychosocial system "man" must have an appropriate musical stimulus and an integrating exercise connected with it. He developed the first Biodanza exercises corresponding to one of the two poles in his model (see table 1). He used particular music to reinforce the identity pole (euphoric rhythms) and other music to induce states of regression. 
Table 1. First exercises for the poles "identity” and "regression” (Garcia, 1997)

\begin{tabular}{|ll|ll|}
\hline \multicolumn{1}{|c|}{ Identity } & & \multicolumn{1}{c|}{ Regression } \\
\hline$\bullet$ & Physiological Walking & $\bullet$ & Choir on a Single Syllable \\
- Challenging Exercises & - Slow Neck Circles \\
- Expressive Dance with Strength and Purpose & - Relaxation Dances \\
- Communication Dances & $\bullet$ & Movements in Slow Motion \\
- Encounters & - Rocking Circles \\
- Creative Dances & - Compact Trance Groups \\
\hline
\end{tabular}

\section{Experience as the Basic Method in Biodanza:}

R. Toro (Toro, 1995) emphasised that Biodanza is a technique. This Biodanza technique is based on the induction of experiences - the vivencias ${ }^{1}$. The concept of experience in Biodanza is drawn from the philosopher and pedagogue W. Dilthey (cited in Kallen, 2003). Dilthey postulated that it was the role of the arts to understand the human world "to the extent that human states are experienced, to the extent that they are expressed and to the extent that these expressions are understood". Biodanza has adopted this principle encouraging the experience of authentic expression of feelings and an intense state of being. Experience is the intense and passionate perception of being alive in the here and now. It involves an intuitive perception of the moment with maximum intensity and goes beyond rational understanding (Garcia, 1997). Subjective experience takes place in the present. Rational understanding is an interpretation of the present and is retrospective or prospective (e.g., fantasies, imaginings). Experiences or vivencias in Biodanza are evoked by music, dance, songs, and interpersonal contacts within a group, and are expressed in the five lines of human potential. They influence the immunological, physiological, endocrinological, and emotional compensatory processes of an organism and have healing, regenerative effects (organic renewal, Garcia 1997).

The Lines of Experiences (vivencias):

An important aspect in the definition of Biodanza is the learning or re-learning of primal life functions, such as being in contact with human instincts. According to R. Toro (Toro, 1995) common life functions or basic human potentials exist in all humans. Depending upon their genetic potential all humans develop 5 potentials in 5 lines of experience. These consist of vitality, emotionality, creativity, sexuality, and transcendence. These five levels of experience are connected to one another and reinforce each other. Through Biodanza all levels can be stimulated and harmonised. The following paragraph describes the possible effects of these so-called "five lines" as outlined in Biodanza by R. Toro (Toro, 1995):

- Vitality (meaning health, alternation between activity and relaxation, joy):

The vivencias for vitality are intended to revitalise the body, lead to improved health, increase physical auto-regulation, and uncover or discover the joy of living and serving the life force.

- Sexuality (referring to the ability to experience pleasure, reproduction, sexual connection): The vivencias for sexuality increase the ability to experience pleasure, strengthen sexual identity, improve the ability to make contact with others and increase sensual sensitivity.

- Creativity (means innovation, construction, imagination):

The vivencias for creativity stimulate abilities in expression and the ability to structure one's life in a meaningful way. Different forms of expression can be experimented with on this level

$1=$ Experience, intensively experienced moment 
and new creative possibilities of expression can be found.

- Emotionality (referring to sensitivity, love, friendship, altruism):

The vivencias of emotionality allow for a sensitive re-orientation as well as enable new access to emotions. Furthermore, more appropriate forms of emotional regulation and empathy can be learned that can be used in dealing with oneself as well as in developing emotional relationships with others then.

- Transcendence (refers to an expansion in consciousness, connection with nature, a feeling of belonging in the universe):

The vivencias of transcendence attempt to expand consciousness and create a harmonic, holistic, integrative perspective on the world.

\section{Protovivencias:}

The development of identity is a lifetime process that is influenced by our first experiences - the protovivencias ${ }^{2}$. The source of the 5 lines of experiences or of our identity is our primal, intra-uterinal experience, our so-called oceanic experience (Jung, 1980). In the first six months of life these primal, oceanic experiences are differentiated by means of sudden flash experiences (flash-learning) and as a response to internal and external stimuli. The oceanic experiences are differentiated into the following protovivencias (Timbergen, 1952, cited in Lopez, 1952):

- The protovivencia connected to vitality results from the baby's movement and is based on the fluctuation between activity and relaxation or the experiences of arousal and rest.

- Sexuality is connected to the protovivencia associated with skin contact and affection.

- Creativity develops out of the expression of an infant's curiosity.

- Emotionality is connected with the protovivencia associated with eating and protection.

- Transcendence develops out of the protovivencia associated with the harmony that a baby perceives in his or her environment.

In the table that follows (see Table 2) descriptions of the 5 lines of experiences (vivencias) and the associated experiences, emotions and feelings are presented. If for example the protovivencia of protection was experienced as a baby then altruism, which is considered the associated adaptive experience, can be developed later on. If a person has not experienced sufficient protection then it is more likely than not that the person will exhibit fewer altruistic behaviours later.

Table 2. Description of the 5 lines of experience and the associated experiences, emotions and feelings or the "evolutionary" experiences

\begin{tabular}{|l|l|l|l|}
\hline \multicolumn{1}{|c|}{ Protovivencia } & \multicolumn{1}{|c|}{$\begin{array}{c}\text { Line of Experience; } \\
\text { Vivencia }\end{array}$} & \multicolumn{1}{c|}{ Emotion, Feeling } & Adaptive Experience \\
\hline movement, vital energy & vitality & $\begin{array}{l}\text { joy, life impulse, } \\
\text { enthusiasm }\end{array}$ & autonomy \\
\hline contact, affection & sexuality & desires, pleasure & $\begin{array}{l}\text { orgasmic connection, } \\
\text { lust, sensuality }\end{array}$ \\
\hline freedom, expression, curiosity & creativity & creative enthusiasm & $\begin{array}{l}\text { artistic creation, } \\
\text { scientific creation }\end{array}$ \\
\hline protection (security) eating (food) & emotionality & affection, love, friendship, & altruism \\
\hline $\begin{array}{l}\text { harmony (harmonic relationship } \\
\text { with environment), free breathing }\end{array}$ & transcendence & $\begin{array}{l}\text { happiness, serenity, } \\
\text { calmness }\end{array}$ & ecstasy \\
\hline
\end{tabular}

\footnotetext{
${ }^{2}$ Protovivencias are the primal experiences of early childhood.
} 
The lines are connected with each other and can reinforce each other. They take their own individual course in a person's life, depending on the environmental stimuli - the eco-factors. The goal of Biodanza is to express the genetic potentials a person has in the 5 lines of experience and integrate these experiences and behaviours to make the person a biopsychosocial whole (vertical aspect of the theoretical model).

Genetic Potential and Eco-factors:

The development of all beings follows the lines of genetically inherited potentials. The DNA within every cell contains the entire biological information needed for the complete development of the individual. This information manifests itself in the network of the lines of vivencias. Whether or not the genetic potential is able to unfold depends upon the eco-factors. A large part of our potential remains only a "possibility" (potency) due to a lack of sufficient stimulation or to suppression. Positive eco-factors are stimuli and conditions that encourage the development of potentials. According to R. Toro (cited in Kallen, 2003), however, people of our culture are exposed to a strong network of negative eco-factors. To counteract this Toro attempts to create a field of positive eco-factors in one of his Biodanza sessions where the genetic potentials are stimulated in.

\section{Research on Biodanza:}

Since 1998 (Stück, 1998) the influence of Biodanza has been studied and different psychological (e.g. emotion regulation, health psychology), physiological (e.g. skin response, blood pressure) and immunological (specific, non-specific immune response) parameters have been investigated (Stück, Villegas, 2008). Collaborations with several universities and institutes (e.g. University of Leipzig, Institute for Stress Research Berlin, University Abierta Interamericana B. Aires) as well as with the Biodanza School Buenos Aires have been established. Approximately 150 persons have taken part in this investigation, which is based on an Experimental-ControlGroup-Design. It could be demonstrated that Biodanza is able to increase well-being and personal resources and to prevent states of stress. Biodanza improved psychophysiological self-organisation, a work-related capacity to act, and self-efficacy. With respect to the results of these evaluation studies Biodanza gains particular importance when the health political mandate of the World Health Organisation is considered, which seeks progressive health development and primary prevention of stress states.

\section{Biodanza and the Immune System (IgA):}

It could also be shown that improved auto-regulation is connected to increased Immunoglobulin A levels (Kaschka, Aschauer, 1990). Immunoglobulin A (IgA) is an antibody of a specific humoral immune response (Birbaumer, Schmidt, 1999). IgA acts as a first line of defence against complaints such as upper-respiratory tract infections (Roitt et al., 1991). IgA can be measured in the saliva. An increase in $\operatorname{IgA}$ in the saliva can be taken as a sign of improved specific immunological defence. IgA is particularly suited for immunological field studies because it can be examined noninvasively in the saliva (Hennig, 1994; Jemmott et al., 1983). There are few publications evaluating psycho-neuro-immunological training programs or the effects of such training programs on $\operatorname{IgA}$ on more than two points of measurement. The existing studies refer to examinations of a single relaxation session or to results in which the IgA was measured immediately before and after only one single session. Our studies are the first to examine these effects based on 10 points of measurement of IgA in adults. 
To conclude, it can be said that Biodanza is a type of intervention for stress reduction that has two primary components: integration and auto-regulation. Positive effects of Biodanza on the experience of relaxation and on the immune system (for example, IgA), in particular by means of Biodanza's auto-regulative impact, are suspected. Consequently, and in light of former studies and results the central research question is: What is the effect of Biodanza on IgA and on the feeling of relaxation in the process of ten sessions?

\section{AIM OF THE STUDY}

To measure effects of Biodanza on the secretion of Immunoglobulin A in saliva and on the subjective feeling of relaxation before and after the Biodanza sessions.

\section{MATERIALS AND METHODS}

\section{Investigated Biodanza-programm:}

It is assumed that the subjective rating of relaxation and the IgA levels, which can be seen as reflecting the mucosal immune state, can be enhanced by Biodanza. The formal structure of the Biodanza intervention is as follows: 10 two-hour Biodanza sessions were attended by the participants. The participants were given the opportunity to talk about the experiences of the previous session or to ask any questions before each class. The sessions were composed by two experienced Biodanza teachers - Raul Terren and Veronica Toro - who are at the same time the directors of the Biodanza School Buenos Aires. The sessions were instructed by psychologist and teacher of Biodanza A. Villegas (Mendoza/Argentina). The conceptualisation and the administration of these sessions are based on the theoretical Biodanza model (see above).

The different dances within the Biodanza sessions were designed to pass through the states of identity (sympathetic) and regression (parasympathetic) (see Picture 1).

Picture 1. The Biodanza-curve, variation between identity and regression

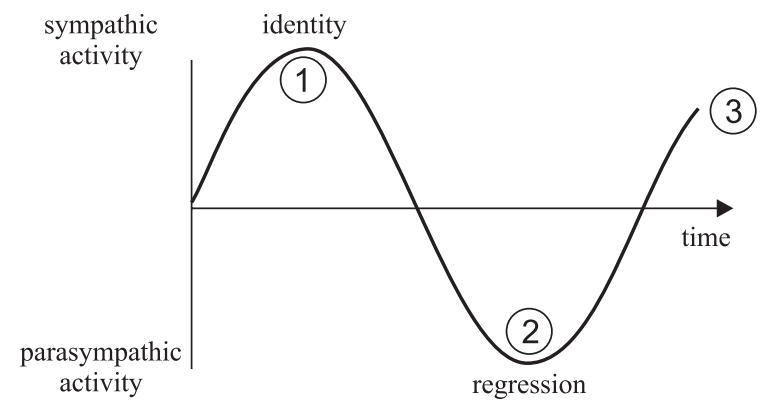

At the beginning of the Biodanza sessions (1) activating dances or vivencias were performed (rhythmic dances, walking). Relaxing, flowing exercises followed (flow dances, segment exercises) in order to lead participants gradually towards regression (2) (rocking circle, compact groups). At the end of the session the state of identity was once again strengthened by means of activating dances (samba, walzes, etc.).

In Table 3 (see Table 3) the main exercises performed in the Biodanza intervention during the 10 sessions are presented. Every session was made up of 12 exercises or dances. According to the progression illustrated in the Biodanza model curve (see Picture 1) dances were repeated or new dances were introduced in the process of the sessions. 
Table 3. The main exercises per session in the Biodanza intervention

\begin{tabular}{|l|l|}
\hline Session & \multicolumn{1}{|c|}{ Main Exercises } \\
\hline $\mathbf{1}$ & $\begin{array}{l}\text { Synergetic walking, rhythmic variations, synergetic jumping, flow dances, five-person affective stroking } \\
\text { of hands, contact with hands and eyes, activating circles }\end{array}$ \\
\hline $\mathbf{2}$ & $\begin{array}{l}\text { Physiological walking, walking in pairs, dance of lightness, harmonising circle, segment dances for } \\
\text { the head and the shoulder-arms, self-stroking of the face, affective stroking of hair in pairs, encounters, } \\
\text { opening to others, activating circles }\end{array}$ \\
\hline $\mathbf{3}$ & $\begin{array}{l}\text { Walking to music, connection to circular rhythm, freeing of movement, tropical dances, harmonising } \\
\text { circle, flow dance in pairs, rocking circle, rocking of the other, circle of eye contact, activating circles }\end{array}$ \\
\hline $\mathbf{4}$ & $\begin{array}{l}\text { Circle of singing, walking in pairs, freeing of the voice and of movement, yin-yang dance, communication } \\
\text { circle, encounters, activating circles }\end{array}$ \\
\hline $\mathbf{5}$ & $\begin{array}{l}\text { Circle of welcoming, walking without worries, play of the hands, rhythmic variations, samba, harmonising } \\
\text { circle, dance of sensitivity, affective stroking of the face in pairs, activating circles }\end{array}$ \\
\hline $\mathbf{6}$ & $\begin{array}{l}\text { Walking in pairs, melodic synchronisation, cascade of segments, dance of earth, water, fire, air, } \\
\text { harmonising circle, affective stroking of the hands in pairs, concentric eye contact circle, encounters, } \\
\text { activating circles }\end{array}$ \\
\hline $\begin{array}{l}\text { Circle of welcoming, rhythmic-sensual walking, dance of the horse, breathing dance, segment dance of } \\
\text { the hips, integration of the 3 centres, encounters, activating circles }\end{array}$ \\
\hline $\mathbf{8}$ & $\begin{array}{l}\text { Rhythmic circle with singing, walking with purpose, meeting the warrior, preparation for the tiger, the } \\
\text { tiger dance, rhythmic relaxation "batucada", harmonising circle, rocking the other, minute of eternity, } \\
\text { contact with hands and eyes, circle of singing }\end{array}$ \\
\hline $\mathbf{1 0}$ & $\begin{array}{l}\text { Circle of welcoming, walking with music, different rhythms, central and peripheral movements } \\
\text { "batucada", leading the other with closed eyes, synaesthetic pleasure, rain of affection, encounters, } \\
\text { activating circles }\end{array}$ \\
\hline
\end{tabular}

\section{Investigation plan and Sample procedure (10 weeks):}

An experimental group of 13 participants took part in the Biodanza-sessions for 10 weeks (weekly class, September-December, 2000). It was a group intervention, so all participants took part at the same time. All participants were healthy teachers from Leipzig (Germany) without any indications of immunopathological processes. Each session lasted for two hours. 10 participants were female, 3 subjects were male. The mean age was 43.08 (SD: 7.55) years. An control group of 11 female teachers from secondary schools of Leipzig and regions near Leipzig took part in a 10 week (September - December, 2000) stress reduction training with elements of yoga (STRAIMY ${ }^{\circledR}$; Stück, 2005). It was a group intervention, so all participants took part in the training at the same time. The mean age was 41.63 (SD: 7.22) years. The youngest teacher was 32 years old, the oldest 57 years. Both groups where chosen by request. All participants were non-smokers who reported no current illnesses or use of medication.

\section{Follow-up examination in the experimental group (Biodanza, 20 weeks):}

After 10 sessions 7 test persons of the experimental group (Biodanza) continued the testing for 10 more sessions. As a control group a group of 6 subjects was examined who did not exercise Biodanza between the $10^{\text {th }}$ and the $19^{\text {th }} / 20^{\text {th }}$ session. The tests of $\operatorname{IgA}$ in saliva were taken before the $19^{\text {th }}$ respectively $20^{\text {th }}$ session.

\section{Saliva collection and analysis:}

IgA in saliva was measured before and after each session. The saliva samples were taken by means of sample tubes with an integrated cotton sponge (Salivette, Greiner, Frickenhausen, Germany). The saliva was collected passively (without chewing) within a time period of 2 minutes. 
That way it was possible to consider the IgA secretion flow rate and the amount of saliva. The saliva samples were kept frozen at $-80{ }^{\circ} \mathrm{C}$ until the analysis. The saliva was separated from the cotton sponge by a centrifuge and gathered in the lower part of the Salivette. Five $\mu$ l of each undiluted saliva sample were placed on radial immuno-diffusion plates for testing secretory IgA (The Binding Side, Birmingham, U.K.). The diameter of the resulting precipitate ring was measured after 96 hours.

\section{Materials for measurement of subjective feeling of relaxation:}

Before and after the sessions, participants rated the subjective feeling of relaxation on a 17 -point scale $(17$ levels not relaxed $=1$; very much relaxed $=17$ ). This scale was developed by U. Binz and G. Wendt (Binz, Wendt, 1986).

The obtaining of the data for IgA and the subjective feeling of relaxation before and after the Biodanza sessions took place according to the following pattern: Firstly, all participants were asked to give a sample of saliva at the same time and, secondly, they were asked to fill out the rating scale shortly thereafter.

\section{Statistical analysis:}

For the comparison of the pre- and post-measurements and also for the Follow-up examination, a t-test for grouped samples was calculated in the experimental group as well as in the control group. Effect sizes for t-tests (dependent samples) were processed with the following

formula: d' $=\frac{\mu_{1}-\mu_{2}}{\sigma_{D}} \sqrt{2}$.

\section{RESULTS}

The results for each group are presented separately.

Experimental Group (Biodanza)

The psychological measurements of the subjective experience of relaxation due to the Biodanza-sessions, which were assessed exactly as the saliva sampling before and after each session, showed 7 significant pre-post changes ( $p<.05$ ) (see Table 4). In the second, third, and ninth session no significant differences were reported but effect sizes point to a substantial increase.

Table 4. Subjective experience of relaxation (average) before (pre) and after (post) the Biodanza sessions

\begin{tabular}{lllllllllll}
\hline Session & $\mathbf{1}$ & $\mathbf{2}$ & $\mathbf{3}$ & $\mathbf{4}$ & $\mathbf{5}$ & $\mathbf{6}$ & $\mathbf{7}$ & $\mathbf{8}$ & $\mathbf{9}$ & $\mathbf{1 0}$ \\
\hline M pre & 8.75 & 9.63 & 11.29 & 8.44 & 7.55 & 9.00 & 9.503 .16 & 8.133 .18 & 13.17 & 10.304 .00 \\
SD & 2.87 & 3.77 & 4.46 & 4.87 & 3.53 & 3.88 & & & 3.19 & \\
M post & 15.40 & 12.75 & 14.71 & 13.33 & 14.27 & 12.4 & 12.60 & 13.50 & 14.17 & 13.403 .27 \\
SD & 1.67 & 5.28 & 1.79 & 2.18 & 3.55 & 3.97 & 3.20 & 2.20 & 1.47 & \\
\hline P & $.01^{* *}$ & .27 & .12 & $.04^{* *}$ & $.00^{* * *}$ & $.02^{* *}$ & $.01^{* *}$ & $.01^{* *}$ & .35 & $.03^{* *}$ \\
d & 3.26 & 0.59 & 0.97 & 1.17 & 2.26 & 1.03 & 1.35 & 1.63 & 0.60 & 1.01 \\
\hline
\end{tabular}

Legend: Significances are indicated for $\mathrm{p}<0.1^{*}, \mathrm{p}<0.05^{* *},{ }^{* * *} \mathrm{p}<0.01 ; \mathrm{d}^{\prime}=$ Effect sizes

The concentration of secretory immunoglobulin A before and after each Biodanza-session differed in 6 out of 10 sessions significantly ( $\mathrm{p} \leq .05$ ) (see Table 5 ). In the $7^{\text {th }}, 8^{\text {th }}, 9^{\text {th }}$ and $10^{\text {th }}$ session no significant differences between pre and post measures could be found. 
Table 5. Average concentrations of secreted Immunoglobulin A before (pre) and after (post) each session

\begin{tabular}{lllllllllll}
\hline Session & $\mathbf{1}$ & $\mathbf{2}$ & $\mathbf{3}$ & $\mathbf{4}$ & $\mathbf{5}$ & $\mathbf{6}$ & $\mathbf{7}$ & $\mathbf{8}$ & $\mathbf{9}$ & $\mathbf{1 0}$ \\
\hline M pre & 33.78 & 38.52 & 27.79 & 35.83 & 29.41 & 30.08 & 43.88 & 83.46 & 44.48 & 46.42 \\
SD & 22.27 & 19.38 & 13.70 & 22.86 & 16.35 & 13.40 & 18.25 & 57.23 & 21.88 & 13.15 \\
M post & 92.10 & 83.71 & 65.71 & 78.40 & 60.45 & 55.67 & 49.68 & 58.78 & 71.20 & 41.64 \\
SD & 36.94 & 32.04 & 37.51 & 35.80 & 31.62 & 28.41 & 25.75 & 30.76 & 39.07 & 21.73 \\
\hline P & $.03^{* *}$ & $.00^{* * *}$ & $.05^{* *}$ & $.02^{* *}$ & $.00^{* * *}$ & $.00^{* * *}$ & .60 & .26 & .25 & .55 \\
d & 2.00 & 2.11 & 1.28 & 1.33 & 1.35 & 1.50 & 0.24 & 0.61 & 0.75 & 0.28 \\
\hline
\end{tabular}

Legend: Significances are indicated for $\mathrm{p}<0.1^{*}, \mathrm{p}<0.05 * *, * * * \mathrm{p}<0.01 ; \mathrm{d}^{\prime}=$ Effect sizes

The measures of the subjective feeling of relaxation and IgA showed a substantial moderate correlation of $\mathrm{r}=.23(\mathrm{p}<.01)$. Across the 10 Biodanza sessions an increase in the pre-measure of subjective feeling of relaxation was observed.

The effect sizes (concerning IgA) in the first 6 sessions $(\geq 1.05)$ of Biodanza point towards a large difference between pre and post measures of IgA. The lack of effects from the seventh session onward may be due to an increase in pre IgA-values. In spite of methodological limitations a first impression shall be presented in table 6 by showing a statistical comparison of the participants' IgA-pre-values (t-test for dependent samples) for the first and last sessions. This should prove helpful for further examinations of long-term effects of Biodanza (see Table 6).

Table 6. Average concentrations of secreted Immunoglobulin A of the pre-values in the first session (pre-value) in comparison to the pre values of the last session (10 ${ }^{\text {th }}$ session)

\begin{tabular}{|l|l|l|}
\hline & $\begin{array}{l}\text { First session } \\
\text { IgA-Pre (Mean, SD) }\end{array}$ & $\begin{array}{l}\text { Last Session } \\
\text { IgA-Pre (Mean, SD) }\end{array}$ \\
\hline Mean (SD) & $33.78(22.27)$ & $46.42(13.15)$ \\
\hline Significance (size of effect d') & $\mathrm{p}=.09^{*}\left(\mathrm{~d}^{\prime}=0,72\right)$ & \\
\hline
\end{tabular}

Legend: Significances are indicated for $\mathrm{p}<0.1 *, \mathrm{p}<0.05 * *, * * * \mathrm{p}<0.01 ; \mathrm{d}$ '= Effect sizes

Follow-up examinations after 10 weeks without Biodanza showed that Biodanza has to be practiced constantly in order to obtain the immunological changes. The IgA-group-averagevalue of the group that did not practice Biodanza sank significantly ( $\mathrm{p}<0.05 * *$, see Picture 2).
Picture 2. Results of the Follow-up examination IgA Biodanza

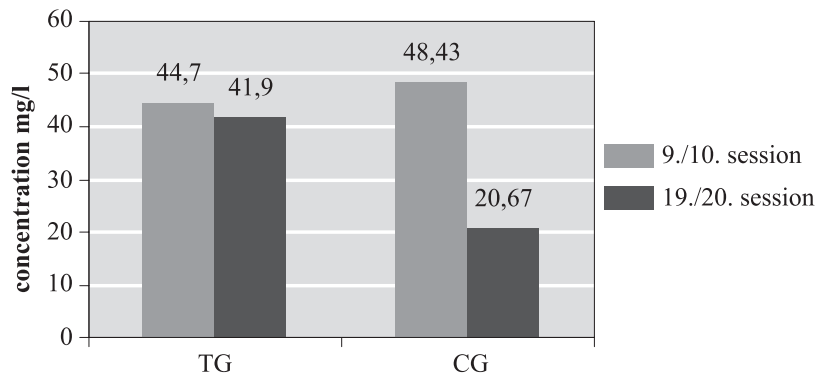


Control group (STRAIMY 1 / Stressreduction with elements of Yoga, Stueck, 2009)

The concentration of secreted immunoglobulin A before and after each STRAIMY ${ }^{\circledR}$ session differed significantly in 6 out of 10 sessions (see Table 7, in comparison to Biodanza: 6 significant pre-post differences, see Table 5). In three sessions (second, sixth and tenth session), the differences were highly significant $(\mathrm{p}<0.01)$. In the $1^{\text {st }}, 5^{\text {th }}$ and the $8^{\text {th }}$ sessions no significant differences between pre and post measures could be found. The effect sizes point to a substantial increase. Across the 10 training sessions a decrease in the pre-measure of IgA was observed.

The psychological measurements of the subjective experience of relaxation due to the training sessions, which were taken exactly as the saliva samplings before and after each STRAIMY ${ }^{\circledR}$-session, showed 8 significant pre-post changes $(\mathrm{p}<0.05)$ (Table 3, in comparison to Biodanza: 7 significant pre-post differences, see Table 4). In three sessions (second, third and tenth session), the differences were highly significant $(\mathrm{p}<0.01)$. In the $1^{\text {st }}$ and the $10^{\text {th }}$ session no significant difference was reported, but effect sizes point to an undeniable difference. Across the 10 training sessions an increase in the pre-measure of subjective feeling of relaxation was observed. The measures of relaxation and IgA showed a substantial moderate correlation of $r=$ $.31(\mathrm{p}<.001)$.

Table 7. Means, Standard-deviations, and t-test for grouped samples for Pre-Post "IgA"

\begin{tabular}{|c|c|c|c|c|c|c|c|c|c|c|}
\hline session & 1 & 2 & 3 & 4 & 5 & 6 & 7 & 8 & 9 & 10 \\
\hline $\begin{array}{l}\text { Pre } \\
\text { Sd }\end{array}$ & $\begin{array}{l}65.47 \\
46.18\end{array}$ & $\begin{array}{l}30.80 \\
15.71\end{array}$ & $\begin{array}{l}76.09 \\
50.98\end{array}$ & $\begin{array}{l}29.15 \\
23.97\end{array}$ & $\begin{array}{l}46.71 \\
25.62\end{array}$ & $\begin{array}{l}36.91 \\
21.81\end{array}$ & $\begin{array}{l}49.84 \\
32.22\end{array}$ & $\begin{array}{l}26.44 \\
14.23\end{array}$ & $\begin{array}{l}42.12 \\
22.35\end{array}$ & $\begin{array}{l}22.33 \\
14.10\end{array}$ \\
\hline $\begin{array}{l}\text { Post } \\
\text { Sd }\end{array}$ & $\begin{array}{l}100.43 \\
46.66\end{array}$ & $\begin{array}{l}116.41 \\
53.36\end{array}$ & $\begin{array}{l}114.91 \\
83.10\end{array}$ & $\begin{array}{l}96.67 \\
63.92 \\
\end{array}$ & $\begin{array}{l}85.60 \\
71.17\end{array}$ & $\begin{array}{l}61.57 \\
27.32\end{array}$ & $\begin{array}{l}94.49 \\
58.99\end{array}$ & $\begin{array}{l}27.06 \\
21.91\end{array}$ & $\begin{array}{l}79.39 \\
43.37\end{array}$ & $\begin{array}{l}93.16 \\
42.16\end{array}$ \\
\hline $\mathbf{P}$ & .13 & $.00 * * *$ & $.07 *$ & $.04 * *$ & .11 & $.00 * * *$ & $.04 * *$ & .94 & $.02 * *$ & $.00 * * *$ \\
\hline d' & 0.92 & 2.18 & 1.06 & 1.56 & 0.97 & 1.46 & 1.03 & 0.03 & 1.11 & 2.80 \\
\hline
\end{tabular}

$* \mathrm{p}<.10, * * \mathrm{p}<.05, * * * \mathrm{p}<.01$, Effect size $\mathrm{d}$ for t-tests (dependent samples):

$\mathrm{d}^{\prime}=\frac{\mu_{1}-\mu_{2}}{\sigma_{D}} \sqrt{2}$

Table 8. Means, Standard-deviations, and t-test for grouped samples for Pre-Post "Relaxation"

\begin{tabular}{|c|c|c|c|c|c|c|c|c|c|c|}
\hline session & 1 & 2 & 3 & 4 & 5 & 6 & 7 & 8 & 9 & 10 \\
\hline Pre $\begin{array}{r}\bar{x} \\
\text { sd }\end{array}$ & $\begin{array}{l}8.80 \\
2.95\end{array}$ & $\begin{array}{l}8.22 \\
2.94\end{array}$ & $\begin{array}{l}8.63 \\
3.85\end{array}$ & $\begin{array}{l}8.67 \\
3.01\end{array}$ & $\begin{array}{l}9.50 \\
3.39\end{array}$ & $\begin{array}{l}10.18 \\
2.44\end{array}$ & $\begin{array}{l}9.60 \\
2.91\end{array}$ & $\begin{array}{l}10.75 \\
2.49\end{array}$ & $\begin{array}{l}10.55 \\
3.21\end{array}$ & $\begin{array}{l}12.63 \\
2.62\end{array}$ \\
\hline $\begin{array}{r}\text { Post } \begin{array}{r}\bar{x} \\
\text { sd }\end{array}\end{array}$ & $\begin{array}{l}13.80 \\
3.49\end{array}$ & $\begin{array}{l}13.67 \\
2.24\end{array}$ & $\begin{array}{l}13.63 \\
1.41\end{array}$ & $\begin{array}{l}13.33 \\
1.03\end{array}$ & $\begin{array}{l}13.83 \\
1.47\end{array}$ & $\begin{array}{l}13.73 \\
1.95\end{array}$ & $\begin{array}{l}12.30 \\
3.68\end{array}$ & $\begin{array}{l}14.63 \\
1.06\end{array}$ & $\begin{array}{l}13.45 \\
1.97\end{array}$ & $\begin{array}{l}13.50 \\
1.20\end{array}$ \\
\hline $\mathbf{p}$ & .10 & $.00 * * *$ & $.00 * * *$ & $.01 * *$ & $.04 * *$ & $.00 * * *$ & $.02 * *$ & $.01 * *$ & $.01 * *$ & .29 \\
\hline d' & 1.32 & 2.23 & 1.72 & 2.07 & 1,53 & 1.61 & .81 & 2.03 & 1.09 & .43 \\
\hline
\end{tabular}

$* \mathrm{p}<.10, * * \mathrm{p}<.05, * * * \mathrm{p}<.01$, Effect size $\mathrm{d}$ for t-tests (dependent samples):

$\mathrm{d}^{\prime}=\frac{\mu_{1}-\mu_{2}}{\sigma_{D}} \sqrt{2}$ 


\section{Discussion}

With this pilot study the first time the effects of Biodanza on the secretion of Immunoglobulin A and on the subjective feeling of relaxation were investigated.The subjective evaluation of the state of relaxation proved to be between 8 and 13 raw points in the 10 pre-measures. Participants felt slightly uneasy, grumpy and nervous before the sessions. After seven out of ten sessions the state of mind of participants changed and they became more calm, relaxed, and self-composed. All effect sizes point towards a real difference between pre and post measures of relaxation in the 10 sessions. The subjective relaxation measures drawn from participants in the Yoga-based training sessions showed significant pre-post changes in eight out of ten sessions (Stueck et al., 2003). The results of the IgA measure before and after each session showed a significant postsession increase in 6 out of 10 sessions $(\mathrm{p} \leq .05)$. The effects of Biodanza are held responsible for the effects found. The measurement of Immunglobulin A taken in the context of the Yoga-based training sessions (Stueck, et al., 2003) showed significant pre-post changes in 6 out of 10 sessions $(\mathrm{p} \leq .05$, in one session significant tendency: $\mathrm{p} \leq .1$ ) (Stueck et al., 2003). Therefore, the autoregulative effects found in the participants of the Biodanza intervention are comparable to those found in participants of the Yoga-based training sessions. This finding can further be supported by other studies with adults, which have found moderate correlations between auto-regulative trainings and increases in the secretion of IgA (Green R. G., Green M. L., 1987; Jasnoski, Kugler, 1987; Green M. L., Green R. G., Santoro, 1988). Our studies concerning Biodanza and the Yogastudy (Stueck et al., 2003) are the first to examine these effects based on 10 points of measurement in adults.

The negative changes in the experimental group (that means decrease of the postmeasurements compared to the pre-measurements of session 8 and $10^{3}$ ) suggest that Biodanza does not belong to the group of classic relaxation trainings, wherein a clear relaxation-inducing impulse evokes a clear short-term relaxation reaction, too, including the accompanying immune competence increases. This became apparent in the exclusively positive changes during the Yoga intervention. As already outlined, Biodanza is an emotional training expressing every kind of emotion through dancing, which can also have negative effects on IgA, of course. Studies concerning expression of anger (Martin, Dobbin, 1988) and stress respectively niveaus of strain (McClelland, 1982, Jemmott et al, 1983) and concerning other emotional reactions (z.B. sadness) prove the relation between the mentioned emotions and IgA-reduction. That emotion-specific immunologic mechanism of action should be examined further. The discerned linear cause-effect relationship between relaxation impulse and IgA-increase in Yoga and other relaxation methods (Green et al., 1988, 1987, Stueck et al., 2003) seems to have only limited application on Biodanza. Furthermore, Biodanza could have a stronger stimulus for long-term changes concerning the IgA-Immune-Reaction compared to Yoga. The inferential statistical analysis showed a significant difference between participants' first and last sessions on a $10 \%$ significance level ( $\mathrm{p}=.09 *)$. Nonsignificant pre-post-differences in sessions 7 to 10 of the experimental group (Biodanza) as well as the negative effects of sessions 8 and 10 can be explained by increased pre-values among other things (e.g. regulation of emotions). That would point to a transfer concerning an improved immune response that means to a longer-term effect of Biodanza on IgA. With the Yoga training

\footnotetext{
${ }^{3}$ e.g. in session 8: the dance of the tiger with anger expression and strong adrenergic stimulation, in session 10 : dances of triumph in the end of the session.
} 
this transfer does not appear in the prevalues. Figure 3 illustrates this important new finding. This effect is called "Transtase" and underlines the effect of self-organizing systems, wherein a new quality state (JUMP) in the regulation of $\operatorname{IgA}$ is reached (see Picture 3).

The theory of Transtase is a typical term of theoretical model of Biodanza and is based on the theory of Systems (Terren, 2009). The difference between autoregulation and selforganisation is defined as following (Terren, 2009). A system which receives stimulation tries to autoregulate and therefore to balance itself (see Picture 3, level 1) until a certain level of instability, pressure or stimulation forces the system to jump to a new level. Because holding the old state is not possible. This means the instability (chaos) causes a new quality and structure of the system (selforganisation of systems, see picture 3, jump and level 2). This Process Model of biological systems was also described by, H. U. Balzer and K. Hecht (Balzer, Hecht, 2000) in several investigations concerning the regulation of periods lengths of the skin response connected with stress (see Picture 4). This "Transtase" -effect could be proofed in our study the first time.

This long-term aspect has to be interpreted with caution and should be further examined with larger samples and further examined with larger samples and with a design that examines the EG and CG (e.g. via variance analysis with repetitive measuring) directly. Unfortunately the described long-term changes (esp. follow-up study) and the negative effects due to methodical defects (i.a. sample too small, missing statistical EG-CG evaluation with MANOVA) cannot be analyzed more thoroughly. That should definitely happen in further studies.

\section{CONCLUSIONS}

Biodanza encourages achieving of a significant effect with regard to the improvement of the IgA level in saliva. This fact speaks in favour of immuno-enhancing effects that should reduce the susceptibility to minor infections. With respect to the subjective experience of relaxation, Biodanza has a particularly positive effect on this autoregulative aspect of stress reduction.

For future research in the field of immunological and psychological evaluations of Biodanza the 
following is suggested: Further research should address the issue of gender-specific differences in the effects of Biodanza on immunological parameters. In order to be able to assess circadian influences on the human organism and thus be able to properly interpret our results further evaluation studies related to this topic should be carried out. Furthermore, it would be interesting to explore which changes of emotional well-being correlate with changes in IgA concentration and whether a correlation between personality factors and secretory Immunoglobuline A exists.

\section{REFERENCES}

1. Balzer, H. U., Hecht, K. (2000) Chrono-Biologische-Regulationsdiagnostik (CRD). Ein neuer Weg zur objektiven Bestimmung von Gesundheit und Krankheit [Chrono-Biological Regulation Diagnostic (CRD). A New Path to the Objective Assessment of Health and Disease]. In: K. Hecht, H. U. Balzer (Eds.) Stressmanagement, Katastrophenmedizin, Regulationsmedizin, Prävention. Lengerich: Pabst Science Publishers, S. 134-155 (in German).

2. Binz, U., Wendt, G. (1986) Kurzskala Stimmung/Aktivierung [Short Scale of Mood and Activity]. Weinheim: Beltz, S. 14-45 (in German).

3. Birbaumer, N., Schmidt, R. F. (1999) Biologische Psychologie [Biological Psychology]. Heidelberg: Springer, S. 1-234 (in German).

4. Biswanger, L. (1973) Essere nel mondo [To be in the World]. Roma: Astrolabio, p. 23-25 (in Italian).

5. Garcia, C. (1997) Biodanza. Die Kunst das Leben zu tanzen. Erleben als Therapie [Biodance. The Art to Dance the Life. Experience as a Therapy]. Unveröffentlichtes Manuskript, Fischamend, Österreich (in German).

6. Green, R. G., Green, M. L. (1987) Relaxation Increases Salivary Immunoglobulin. Al. Psychol. Rep. No 61, p. 623-629.

7. Green, M. L., Green, R. G., Santoro, W. (1988) Daily Relaxation Modifies Serum and Salivary Immunoglobulins and Psychophysiologic Symptom Severity. Biofeedback and Self-Regulation, 13, p. 187-199.

8. Hennig, J. (1994) Die psychobiologische Bedeutung des sekretorischen Immunglobulin A im Speichel. [The Psycho-Biological Meaning of the Secretory Immunglobuline A in Saliva]. Münster: Waxmann, S. 1-16 (in German).

9. Jasnoski, M., Kugler, J. (1987) Relaxation, Imagery and Neuroimmunomodulation. Annuals of the New York Academy of Sciences, 496, p. 722-730.

10. Jemmott, J. B., Borysenko, M., Chapman, R., et al. (1983) Academic Stress, Power Motivation, and Decrease in Secretion Rate of Salivary Secretory Immunoglobulin A. The Lancet 1(8339), p. 14001402.

11. Jung, K. G. (1980) Die Archetypen und das kollektive Unbewusste [The Archetypes and the Collective Unconsciousness]. Bollati: Turin, S. 1-474 (in German).

12. Kallen, H. W. (2003) Der Tanz des Lebens und seine biologischen Grundlagen. Lebenslänglich Biodanza? [The Dance of Life and Biological Backgrounds. Lifelong Biodanza?]. Unveröffentlichte Monographie (in German).

13. Kaschka, W. P., Aschauer, H. N. (1990) Psychoimmunologie [Psycho-Immunology]. Stuttgart: ThiemeVerlag, S. 3-24 (in German). 
14. Lopez, I. (1952) El descubrimiento de la intimitad [The Discovery of Intimacy]. Madrid: Aguilar S. A., p. 1-74 (in Spanish).

15. Martin, R. A., Dobbin, J. P. (1988) Sense of Humor, Hassles, and Immunoglobulin A: Evidence for a Stress-Moderating Effect of Humor. Int J Psychiatry Med. No 18, p. 93-105.

16. Mc Clelland, D. C., Alexander, C., Marks, E. (1982) The Need for Power, Stress, Immune Functions, and Illness among Male Prisoners. Journal of Abnormal Psychology, No 91, p. 61-70.

17. Roitt, I. M., Brostoff, J., Male, D. K. (1991) Kurzes Lehrbuch der Immunologie [Short Textbook of Immunology]. Stuttgart: Thieme-Verlag, S. 1-399 (in German).

18. Stück, M. (1998) Entspannungstraining mit Yogaelementen in der Schule. Wie man Belastungen abbauen kann [Relaxation Training with Elements of Yoga in Schools. How to Deal with Pressure] Donauwörth: Auer, S. 1-60 (in German).

19. Stück, M. (2000) Entspannungstraining mit Yogaelementen in der Schule. Kursleiter-Handbuch [Relaxation Training with Elements of Yoga in Schools. Trainer Manual]. Donauwörth: Auer, S. 60 (in German).

20. Stueck, M., Meyer, K., Rigotti, Th., Bauer, K., Sack, U. (2003) Evaluation of a Yoga-based Stress Management Training for Teachers: Effects on Immunoglobulin A Secretion and Subjective Relaxation. Journal of Meditation and Meditation-Research, Vol. 3, p. 59-68.

21. Stück, M., Sonntag, A., Balzer, H. U., Glöckner, N., Rigotti, Th., Schönichen, C., Hecht, K. (2005) Hypersensibilitätszustände der elektrodermalen Aktivität und Belastungserleben im Lehrerberuf [Hypersensitivity Statuses for Electrodermal Activity and Feeling of Pressure Amongst Teachers]. Psychomed, No 17 (2), S. 109-114 (in German).

22. Stueck, M., Villegas, A., Terren, R., Toro, V., Mazzarella, L., Schröder, H. (2008) Die Belastung tanzen? Biodanza als neue körperorientierte psychologische Interventionsmethode der Belastungsbewältigung für Lehrer [Dance the Stress? Biodanza as New Body-Orientied Psychological Interventive Method for Stress-Coping of Teachers]. Ergo-Med, No 02/2008, S. 34-43 (in German).

23. Stueck, M., Villegas, A. (2008) Dance Towards Health? Empirical Research about Biodanza. In: M. Stueck, A. Villegas (Hrsg.) Biodanza im Spiegel der Wissenschaften [Biodanza in the Mirror of Sciences]. Bd. 1. Strasburg: Schibri-Verlag, S. 344 (in German).

24. Stueck, M. (2009) Stressreduction with Elements of Yoga (STRAIMY $\left.{ }^{\circledR}\right)$. Strasburg: Schibri-Verlag, 78 p.

25. Terren, J. (2009) Autoregulation and Selforganisation. Unpublished Material Biocentric Education. School of Biodanza Leipzig (www.biodanzaschule-leipzig.de) $44 \mathrm{p}$.

26. Toro, R. (1995) The Theory of Biodanza. Unpublished Materials of School of Biodanza Leipzig (www. biodanzaschule-leipzig.de) $60 \mathrm{p}$.

\section{PhD Marcus Stück}

Institute of Applied Psychology, University of Leipzig

Address: Seeburgstr. 14-20, D-04103

Leipzig phone: 03419735956

Fax: 03419735958

E-mail: stueck@rz.uni-leipzig.de

www.bildungsgesundheit.de

www.biodanzaschule-leipzig.de

\section{Mg. Sc. Alejandra Villegas}

Institute of Applied Psychology, University of Leipzig

Address: Seeburgstr. 14-20, D-04103 Leipzig

E-mail: villegas@rz.uni-leipzig.de www.biodanzaschule-leipzig.de 


\section{Katrin Bauer}

Institute of Clinical Immunology and Transfusion medicine, University of Leipzig

Address: Johannisallee 30, D-04103 Leipzig

Phone: 03419725503

Fax: 03419725839

E-mail: bauk@medizin.uni-leipzig.de

\section{PhD Ulrich Sack}

Institute of Clinical Immunology and Transfusion medcine [medicine], University of Leipzig Address: Johannisallee 30, D-04103 Leipzig

Phone: 03419725503

Fax: 03419725828

E-mail: mail@ulrichsack.de

\section{Raul Terren, Veronica Toro}

Universidad Abierta Interamericana, B. Aires Address: Chacabuco 90 - $1^{\circ}$ Piso, Capital Federal Phone: 4342-7788 (Rotativas)

E-mail: uai@vaneduc.edu.ar 